\title{
A szabad gyökös reakciók jelentősége a szívizom ischaemiás-reperfúziós károsodásában és az endogén adaptáció indukálásában
}

\author{
Rőth Erzsébet dr. \\ Pécsi Tudományegyetem, Szentágothai János Kutatóközpont, Pécs
}

\begin{abstract}
Az aerob élőlények szöveteiben az oxigénellátás legkisebb zavara is súlyos károsodásokhoz vezethet. A keringés helyreállítása, az úgynevezett reperfúzió, az egyetlen alternatíva a sejtek életképességének megőrzésére, amelynek azonban kimenetelét alapvetően meghatározza a keringés helyreállítása előtt eltelt ischaemiás idő hossza. Ha ez az időtartam meghaladja a reverzibilis elváltozások zónáját, létrejönnek a reperfúziós károsodások, amelyek szívizom esetében aritmiát, a kontraktilis erő csökkenését, végül a sejtek elhalását okozzák. Kísérleteink során bizonyítottuk, hogy a reperfúzió során robbanásszerüen keletkező reaktívoxigén-származékok gyorsítják a szívizom-károsodás kialakulását, de amennyiben kisebb mértékű és rövidebb idejü a reperfúziót megelőző időtartam, akkor a szabad gyökök génindukcióhoz és az antioxidáns enzimek fehérjéinek szintéziséhez vezetnek. A reperfúziónál keletkező szabad gyökök úgynevezett Janus-arcú viselkedése vezetett ahhoz, hogy szerepüket kísérletes munkánk során a szívizom endogén adaptációs folyamatában megvizsgáljuk. Orv. Hetil., 2015, 156(47), 1908-1911.
\end{abstract}

Kulcsszavak: szívizom ischaemia-reperfúzió, szabad gyökök, endogén adaptáció

\section{The role of free radicals in the myocardial reperfusion injuries and in the development of endogenous adaptation}

\begin{abstract}
The reperfusion of acute ischaemic myocardium is essential for myocardial salvage, so called "gold standard" therapy, however it can results serious damage in the myocardium. Functional alterations occur, including depressed contractile function and decreased coronary flow as well as altered vascular reactivity. Over the several decades it has been demonstrated that oxygen radical formation is greatly increased in post-ischaemic heart and serves as a critical central mechanism of ischaemic-reperfusion injury. However it has been demonstrated that free radical play an important role in the endogenous adaptation phenomenon of the heart, too. Ischaemic preconditioning is a cellular adaptive response of the heart to stress, which provides the most potent endogenous protection against reperfusion arrhytmias, stunning and infarction. Postconditioning defined as brief periods of ischaemia and reperfusion during the very early minutes of reperfusion stimulates endogenous adaptation. Postconditioning may also attenuate the damage to endothelial cells and cardiomyocytes from oxidants, cytokines, proteases and inflammatory cells.
\end{abstract}

Keywords: myocardial ischaemia-reperfusion, free radicals, endogenous adaptation

$R$ thth, E. [The role of free radicals in the myocardial reperfusion injuries and in the development of endogenous adaptation]. Orv. Hetil., 2015, 156(47), 1908-1911.

(Beérkezett: 2015. augusztus 18.; elfogadva: 2015. szeptember 13.)

Az orvostudomány jelentős fejlődése révén a várható élettartam az Európia Unió országaiban is jelentősen növekszik. A szívizominfarktus a javuló statisztikai adatok ellenére is az egyik legsúlyosabb életveszélyes kórállapot. Gyakorisága a fiatalokat tekintve csökkenő tendenciát mutat, azonban a negyvenes korosztálynál pregnánsan jelen van. Emellett emelkedik a nők aránya a megbetege- dettek körében, bár 6-8 évvel későbbi életkorban jelentkezik a betegség, mint férfiaknál, és az ebből származó hospitalizáció és halálozás magasabb. Magyarországon évente 20-25 ezer új beteget regisztrálnak. A halálozási statisztikák releváns csökkenése annak is köszönhető, hogy lényegesen több beteg jut időben kórházba és korábban kapja meg az adekvát kezelést. A szívinfarktus ri- 
zikófaktorai közé tartozik az endotheldiszfunkció, hyperlipidaemia, diabetes mellitus, dohányzás, mozgásszegény életmód és a szabadgyök-képződéssel járó oxidatív és nitrozatív stressz [1].

\section{A szívizom ischaemiás-reperfúziós károsodásai}

A coronariaelzáródást követő myocardialis hypoxia és ischaemia kezelésében a jelenleg elfogadott „gold standard" az érintett terület keringésének minél gyorsabb helyreállítása. A reperfúziós terápia azonban paradox következményekkel jár, amelyet összefoglalóan reperfúziós károsodásnak nevezünk $[2,3,4,5]$.

A reperfúzió komplex folyamat, amely többféle sejt aktiválódásához vezet (endothelsejtek, neutrophil granulocyták, thrombocyták, monocyták, makrofágok, valamint szívizomsejtek), aminek következményei: gyulladásos mediátorok felszabadulása, oxidatív stressz, ionos és metabolikus zavarok, apoptózis és nekrózis, sejt- és molekuláris szintű szignálfolyamatok aktiválódása [6, $7,8]$.

A szöveti hypoxia során az anaerob metabolizmus következményeként kialakul az acidózis, emelkedik az intracelluláris $\mathrm{Ca}^{++}$-szint, a magas energiájú foszfátok, mint az ATP és a kreatinfoszfátok szintézise leáll, amelynek következtében energetikai és homeosztáziszavarok jönnek létre. Szívizom esetében, e károsodások következtében különböző ritmuszavarok alakulnak ki, a ventricularis arrhythmia különböző formái [9], a szívizom pumpafunkciójának zavara, amely a kontraktilis diszfunkció (stunning) eredménye, illetve a szívizomsejtek reverzibilis vagy irreverzibilis károsodása. Sokáig vitatott volt, hogy e folyamatokban a szabad gyököknek milyen szerepe van. Saját kísérleteinkben, amelyeket az 1980-as évek elején, altatott állatokon végeztünk a bal leszálló coronariaartéria leszorításával (1, 2, 3, 24 óra), kimutatható volt a szívizomból vett homogenizátumban az infarktusterületen a lipidperoxidáció fokozódása, a gyököket közömbösítő redukáltglutation-tartalom és az antioxidáns enzim, szuperoxid dizmutáz aktivitásának csökkenése [10]. A szövetek és a sejtek védelmének azonban egyetlen lehetséges módja a letális károsodás fellépése előtt, hogy a keringést helyreállítva újra biztosítsuk a megfelelő oxigénellátást, a magas energiájú foszfátok reszintézisét. Így a reperfúzióval, vagyis a keringésből kizárt terület vérellátásának megteremtésével az előzően károsodott szívizomsejtekben vagy visszafordítjuk a patológiás folyamatokat (reverzibilis károsodások zónája), vagy azokat felgyorsítva még gyorsabban bekövetkezik a sejtelhalás (irreverzibilis károsodások zónája). A szabad gyökök meghatározó patológiás szerepe valóban a reperfúzió során vált ismertté, számos olyan módszer alkalmazásának bevezetésére ösztönözve a kutatókat, amellyel ezeket a károsodásokat csökkenteni lehet.

A keringésből kizárt coronariaartériába juttatott oxigenizált friss vér már néhány szekundum-perc alatt drá- mai változásokat indít el, amelynek markáns megnyilvánulása a robbanásszerüen keletkező szabad gyökök, amelyek a továbbiakban a membránfoszfolipidek oxidálásával elindítják a sejtkárosodás folyamatát. $M c \operatorname{Cord}[2]$ nevéhez füződik, hogy a hypoxia-ischaemia alatt az ATP lebontása során keletkező hypoxantin-xantin szubsztrátjaként szolgál az endothelsejtekben aktiválódó xantinoxidáznak, amely a reperfúziós vérben lévő oxigénnel nagy mennyiségű szuperoxidgyököt termel. Ugyanezen időben aktiválódik a polimorf neutrophil granulocyták felszínén lévő NADPH-oxidáz, amely szintén a szuperoxidgyök-termelésben játszik meghatározó szerepet, illetve a fehérvérsejtekben lévő mieloperoxidáz enzim, amely a reperfúzió során megjelenik a szérumban és a szívizomszövetben, markerként használható a kialakuló reperfúziós károsodás mértékének megítélésére. Még e korai reperfúziós fázis során aktiválódik a komplement (C5A), illetve a különböző lipidmediátorok (tromboxán, leukotriének), amelyek jelentős vasoconstrictiót indukálva az úgynevezett „no reflow” fenomén kialakulásához vezetnek. A reperfúzió ezen akut, korai időszakát követően mutathatók ki a receptorszintû elváltozások, amelyek magukba foglalják a mitogénaktivált proteinkinázok és transzkripciós faktorok aktiválódását [11, 12]. A szabad gyökök kétarcúsága (káros/védő) e szignálfolyamatok jobb megismerése során vált egyértelmúvé, hiszen kísérleteink során, az irodalommal megegyezően, kimutattuk, hogy amennyiben a reperfúzió okozta stressz kismértékű volt, a génindukcióhoz és a védőfehérjék (antioxidáns enzimek fehérjéi, hősokkproteinek) szintéziséhez vezetett, míg ha a hypoxia időtartama nagyobb volt, akkor a gyulladásos citokinek (tumornekrózisfaktor- $\alpha$, interleukin-1, -6) termelése nőtt meg. Ennek alapján elsőként írtuk le, hogy a szívizom reperfúziója során, az úgynevezett reperfúziós paradoxon mellett, kialakul az oxidatív stressz paradoxona, amely vagy gyorsítja a szívizomnekrózis kialakulását, vagy kisebb stressz esetén a transzkripciós faktorok aktiválása eredményeként védő enzimeket, fehérjéket állít elő [13].

\section{A szabad gyökök szerepe az endogén adaptációban, prekondicionálás}

Mindazon mütétek során, ahol a szívizom keringésének helyreállítása a cél - coronariaintervenciók, stentbeültetés, coronariabypass-mútét -, a reperfúziós károsodások minimalizálása meghatározza a betegek késóbbi sorsát, a szív teljesítőképességét és az életminőséget. Ma már tudjuk, hogy a szervezet belső védőrendszereinek az indukálásában a szabad gyököknek meghatározó szerepe van. A Murry által 1986-ban felfedezett endogén adaptációs stimulus kiváltásához, az úgynevezett prekondicionáláshoz a szabad gyökök jelenléte elengedhetetlen [14]. Ennek lényege, hogy a szubtoxikus stressz hatására keletkező mediátorok, amelyek részben receptorfüggőek (adenozin, bradikinin, opioidok), illetve receptorfüggetlen mediátorok (oxigéneredetû szabad gyökök, NO) 
megfelelő addíciója esetében alakul csak ki a védelmi mechanizmus. Ennek lényege, hogy a többszörösen alkalmazott kis időtartamú coronarialeszorítás és reperfúzió következtében a mediátorok addíciója jön létre, amely eléri az úgynevezett prekondicionálási küszöbszintet, létrehozva a szívizom védelmét. A Murry által 1986-ban felfedezett klasszikus prekondicionálás időtartama 3-6 óra között változott, amelynek hatására csökkentek a reperfúziós aritmiák, a myocardialis stunning és az infarktusterület nagysága. Az, hogy ez a védelem bármilyen beavatkozás nélkül ismét megjelenik 24 óra múlva, az úgynevezett „second window of protection” (SWOP) elnevezést kapta, megerősítette a kétféle időpontban jelentkező védelem különféle kiváltó mechanizmusát. (A korai védelem az ATP-függő káliumcsatornákon jön létre, a késői védelemben az újonnan szintetizált védő fehérjék játsszák a főszerepet [15].)

Kutatócsoportunk a késői prekondicionálás sertéseken történő kísérletes vizsgálatával ért el nemzetközileg is elismert eredményeket [16, 17, 18]. Zárt mellkasú sertésmodellben többszörös intracoronariás ballonfelfújással létrehozott késői prekondicionálás modelljében az angiotenzinkonvertázenzim- (ACE-) gátló perindoprilát kardioprotektív hatását mutattuk ki, amely a bradikinin mint trigger lebomlásának gátlásán keresztül járult hozzá a prekondicionálás küszöbszintjének eléréséhez, az infarktusterület csökkentéséhez [16]. Ezeket az eredményeinket erősítette meg a 2007-ben lezárt EUROPA Study, amely eredményei szerint a perindopriláttal kezelt betegeknél az infarktus mortalitása $20 \%$-kal csökkent. Ugyancsak sertésmodellben kimutattuk azt, hogy a prekondicionáláshoz szükséges triggerek összeadódásából kialakuló küszöbértékhez a reperfúziónál felszabaduló szabad gyökök is hozzájárulnak. Ha a gyököket a reperfúzió kezdeténél gyökfogó antioxidánssal lekötjük, a prekondicionálás védőhatása, az infarktusterület csökkentése nem jön létre. Az ígéretes vizsgálatok és a kedvező eredmények ellenére a prekondicionálás nem váltotta be a hozzá füzött reményeket a klinikai alkalmazásban, mivel akut ischaemiában nem alkalmazható, relatíve hosszú eljárás, hatása ischaemiás szívbetegségben és atherosclerosisban kétséges, valamint metabolikus betegségek esetén, mint diabetes, hatása csökken vagy nem indukálható.

\section{A szabad gyökök szerepe a szívizom endogén adaptációjában - posztkondicionálás}

A szívizom prekondicionálással történő védelme klinikai szempontból számos problémát vetett fel. Ennek a problémának a feloldására nyújtott lehetőséget a Vinten-Jobansen és munkacsoportja (2005) által felfedezett posztkondicionálás, amely a keringési szünetet követően, a reperfúzió kezdetén alkalmazott rövid stresszimpulzusok protektív hatását bizonyította [19].
A posztkondicionálás szívizomra kifejtett védőhatásának magyarázatára ismertek a mechanikai, a celluláris és a molekuláris (receptorfüggő) mechanizmusok [20, 21]. A keringés újraindításánál alkalmazott többszöri érelzáródások csökkentik az ischaemiás szívizomba nagy nyomással beáramló vér endothelkárosító hatását, és a szöveti ödémát, valamint az adenozin gyors kimosódását, amely gátolja a fehérvérsejtek aktiválódását és szabadgyök-termelését. A celluláris védelem része a mitokondriális tranzíciós pórusok nyitásának gátlása és az inflammatorikus citokinek termelésének csökkentése. A posztkondicionálás molekuláris mechanizmusában meghatározó az antiapoptotikus reperfusion salvage kinases (RISK-kinázok) aktiválódása, amelyek a myocardialis sejtek apoptotikus és nekrotikus elváltozását csökkentik. Újszülött patkányok szívizomsejt-tenyészetén flow citometriás vizsgálatokkal kimutattuk, hogy oxidatív stressz előidézését követően egy neuroprotektív fehérjével (urocortin) együtt alkalmazott szimulált posztkondicionálás hatásosabban csökkenti a letális sejtkárosodás mértékét [20]. Újszülött patkány szívizomsejt-tenyészetén szimulált ischaemiát-reperfúziót követően az antioxidáns hatást kifejtő glutation $S$-transzferáz enzim gátlásával létrehozott proinflammatorikus MAPkinázok aktiválódását és letális sejtpusztulást a szimulált posztkondicionálás szignifikáns mértékben csökkentette [21].

\section{A szívizom reperfúziós károsodásait csökkentő pre- és posztkondicionálás klinikai jelentősége és alkalmazása}

A pre- és posztkondicionálással kombinált mưtéti stratégiák, az egyre meggyőzőbb eredmények hatására, lassan átkerülnek a kísérletes fázisból a klinikai gyakorlatba. Ovize és munkacsoportja akut myocardialis infarctusos betegeken végzett ballon-angioplasticát, amely során a ballon többszöri elzárásával és felengedésével 36\%-kal csökkentette az infarktusos terület nagyságát a kezelésben nem részesült betegekhez képest. Feltételezték továbbá, hogy a mitokondriális védelem $2,5 \mathrm{mg} / \mathrm{kg}$ ciklosporin jelenlétében csökkentheti a kezelt csoportban az ischaemiás-reperfúziós károsodás súlyosságát. A ciklosporinnal kezelt és nem kezelt csoport az alapvető fizikai paraméterekben nem különbözött egymástól. A ciklosporinnal kezelt betegeknél viszont a kreatinkiáramlás alacsonyabb volt és az infarktusos terület is csökkent [22].

Ovize mellett Vinten-Johansen, Varga és mtsai [23, 24, 25 ] is a farmakológiai pre- és posztkondicionálásban látják a jövőt. Feltételezik, hogy a közeljövőben megjelennek olyan gyógyszerek, amelyek a proteinkináz C epsylon, bradikinin, adenozin, az eritropoetinagonisták aktiválásán keresztül fejtik ki hatásukat és az eddig használt mechanikus módszerekhez hasonló terápiás hatást hoznak létre. 


\section{Következtetés}

Összefoglalóan elmondható, hogy a szívizom ischaemiás/reperfúziós károsodásaival kapcsolatban a klinikumban is alkalmazható eljárások kidolgozásával még számos kérdést szükséges megválaszolni, nevezetesen: az optimális védelmi protokoll meghatározása a megelőző ischaemia időtartamának figyelembevételével, a jelátviteli utak közötti összefüggések feltérképezése és a védelem optimális molekuláris célpontjának meghatározása, tekintettel a bevezetendő gyógyszeres terápiára.

Anyagi támogatás: OTKA pályázati támogatások 19952012 között.

A cikk végleges változatát a szerző elolvasta és jóváhagyta.

\section{Érdekeltségek: A szerzőnek nincsenek érdekeltségei.}

\section{Köszönetnyilvánítás}

A szerző köszönettel tartozik Prof. Dr. Török Bélának, a POTE Kísérletes Sebészeti Intézet volt igazgatójának, aki az 1980-as években az intézet tudományos témái közé a kísérletes szívizom ischaemia-reperfúzió kutatásában a szabad gyökök szerepének vizsgálatát elindította és ebben a munkában számomra biztosította a lehetőséget a szerteágazó kutatásra. Köszönöm a szabadgyök-kutatással összefüggő metodikai háttér kialakításában és a klinikai kutatások megszervezésében $D r$. Lantos János kollégám lelkiismeretes munkáját. Köszönetet mondok mindazon PhD-hallgatóknak, akik 1995-tôl a POTE Kísérletes Sebészeti Intézetében részt vettek a szabadgyök-kutatásban, ebből készítve PhD-disszertációjukat: Dr. Mohammad Jaberansari, Dr. Borsiczky Balázs, Dr. Jancsó Gábor, Dr. Ferencz Andrea, Dr. Rácz Boglárka, Dr. Kürthy Mária, Dr. Cserepes Barbara, Dr. Gasz Balázs, Dr. Balatonyi Borbála.

\section{Irodalom}

[1] Soós, P., Szelid, Zs., Bagyura, Zs., et al.: The cardiovascular disease epidemiology in Hungary, Semmelweis University Heart Center's Strategic Plan. [A szív- és érrendszeri megbetegedések magyarországi epidemiológiája. A Semmelweis Egyetem Kardiológiai Központjának stratégiai terve.] http://semmelweiskutatoegyetem.hu/wp-content/uploads/2012/10/Kardiovaszkularis_strategiai_terv-logokkal.pdf. [Hungarian]

[2] McCord, J. M.: Oxygen-derived free radicals in postischemic tissue injury. N. Engl. J. Med., 1985, 312(3), 159-163.

[3] Röth, E., Török, B., Zsoldos, T., et al.: Lipid peroxidation and cavenger mechanism in experimentally induced heart infarcts. Bas. Res. Cardiol., 1985, 80(5), 530-536.

[4] Downey, J. M.: Free radicals and their involvement during longterm myocardial ischemia and reperfusion. Annu. Rev. Physiol., 1990, 52, 487-504

[5] Bolli, R.: Oxygen-derived free radicals and myocardial reperfusion injury: an overview. Cardiovasc. Drugs Ther., 1991, 5(Suppl. 2), 249-268.

[6] Ferdinandy, P., Schulz, R., Baxter, G. F.: Interaction of cardiovascular risk factors with myocardial ischemia/reperfusion injury, preconditioning, and postconditioning. Pharmacol. Rev., 2007, 59(4), 418-458.

[7] Szijártó, A., Arányi, P., Turóczi, Zs., et al.: Reducing ischemiareperfusion injury and conceptual practical possibilities of vascu- lar surgery. Literature review. [Ischaemiás-reperfúziós károsodás csökkentésének elvi és gyakorlati lehetőségei az érsebészetben. Irodalmi áttekintés.] Érbetegségek, 2009, 16(4), 112-120. [Hungarian]

[8] Jancsó, G., Cserepes, B., Gasz, B., et al.: Effect of acetylsalicylic acid on nuclear factor-kappa $B$ activation and on late preconditioning against infarction in the myocardium. J. Cardiovasc. Pharmacol., 2005, 46(3), 295-301.

[9] Végh, A., Parratt, J. R.: The role of mitochondrial KATP channels in antiarrhythmic effects of ischaemic preconditioning in dogs. Br. J. Pharmacol., 2002, 137, 1107-1115.

[10] Röth, E., Török, B., Pollák, Zs., et al.: Myocardial protection by antioxidant during permanent and temporary coronary occlusion in dogs. Basic Res. Cardiol., 1987, 82(Suppl.), 335-345.

[11] Röth, E., Hejjel, L., Jaberansari, M., et al.: The role of free radicals in endogenous adaptation and intracellular signals. Exp. Clin. Cardiol., 2004, 9(1), 13-16.

[12] Jancsó, G., Lantos, J., Borsiczky, B., et al.: Dynamism of NF- $\kappa$ B and APl activation in the signal transduction of ischaemic myocardial preconditioning. Eur. Surg. Res., 2004, 36, 129-135.

[13] Röth, E., Kürthy, M., Lantos, J., et al.: Reactive oxygen intermediates in the endogenous adaptation of the myocardium. In: Góth, L. (ed.): Reactive oxygen species and diseases. Reaserch Signpost, Trivandrum, Kerala, India, 2007.

[14] Murry, C. E., Jennings, R. B., Reimer, K. A.: Preconditioning with ischemia: a delay of lethal cell injury in ischemic myocardium. Circ. Res., 1986, 74(5), 1124-1136.

[15] Yellon, D. M., Baxter, G. F.: A “second window of protection" or delayed preconditioning phenomenon: future horizons for myocardial protection. J. Mol. Cell. Cardiol., 1995, 27, 1023-1034.

[16] Jaberansari, M. T., Baxter, G. F., Muller, C. A., et al.: Angiotensin-converting enzyme inhibition enhances a subthreshold stimulus to elicit delayed preconditioning in pig myocardium. J. Am. Coll. Cardiol., 2001, 37, 1996-2001.

[17] Röth, E., Jancsó, G., Jaberansari, M. T., et al.: Endogenous cardioprotection and adaptation: a new indication for an ACE inhibition. [Endogén adaptáció és kardioprotekció: az ACE-gátlás új indikációja.] Cardiolog. Hung., 2003, 33, 72-76. [Hungarian]

[18] Jancsó, G., Jaberansari, M. T., Gasz, B., et al.: Bradykinin and ACE inhibition in the cardioprotection. Exp. Clin. Cardiol., 2004, 9, 21-26.

[19] Vinten-Johansen, J., Yellon, D. M.: Postconditioning. A simple, clinically applicable procedure to improve revascularization in acute myocardial infarction. Circ. Res., 2005, 112, 2085-2088.

[20] Cserepes, B., Jancso, G., Gasz, B., et al.: Cardioprotective action of urocortin in early pre- and postconditioning. Ann. N. Y. Acad. Sci., 2007, 1095, 228-239.

[21] Balatonyi, B., Gasz, B., Kovács, V., et al.: The role of the inhibition of glutathione-S-transferase in the protective mechanisms of ischemic postconditioning. Can. J. Physiol. Pharmacol., 2013, 91(8), 625-632.

[22] Ovize, M., Baxter, G. F., Di Lisa, F., et al.: Postconditioning and protection from reperfusion injury: where do we stand? Cardiovasc. Res., 2010, 87(3), 406-423.

[23] Varga, Z. V., Zvara, Á., Faragó, N., et al.: MicroRNAs associated with ischemia-reperfusion injury and cardioprotection by ischemic pre- and postconditioning: protectomiRs. Am. J. Physiol. Heart Circ. Physiol., 2014, 307, 216-227.

[24] Vinten-Johansen, J.: Myocardial protection with postconditioning in cardiac surgery: the importance of the model. EJCTS, 2012, 42, 539-541.

[25] Yang, X. M., Liu, Y., Tandon, N., et al.: Attenuation of infarction in cynomolgus monkeys: preconditioning and postconditioning. Basic Res. Cardiol., 2010, 105, 119-128.

(Rőth Erzsébet dr., Pécs, Ifjúság útja 20., 7624 e-mail: erzsebet.roth@gmail.com) 